\title{
What COVID-19 Reveals About Twenty-First Century Capitalism: Adversity and Opportunity
}

\author{
Susan K. Sell ${ }^{1}$ \\ Published online: 6 November 2020 \\ (c) Society for International Development 2020
}

\begin{abstract}
Twenty-first century capitalism features financialization and monopoly power. A structural perspective of contemporary political economy illuminates how these aspects shape the COVID-19 response. COVID-19 has exposed failures across health care systems, working conditions, supply chains, the depth of inequality, systemic racism, and features of globalization that exacerbate negative outcomes for the many. Examining access to medicines, personal protective equipment and vaccines, inequality and working conditions highlights just some of what is broken and what needs to be fixed. The unsparing challenge and immiseration of COVID-19 offer an opportunity to re-think basic structures of contemporary capitalism and re-imagine a more compassionate future.
\end{abstract}

Keywords Financialization · Intellectual monopoly capitalism · Access to medicines · Inequalities · Globalization · Banking sector $\cdot$ Essential workers

\section{Twenty-First Century Capitalism: What's New?}

While the term 'neoliberalism' remains popular, it has become a very large conceptual tent that obscures some important differences between the sharp shift to markets in the 1970s and 1980s under Reagan and Thatcher and the global capitalism of the twenty-first century. The Reagan/ Thatcher models of economic liberalization featured deregulation, privatization, and the transformation of social protection regimes-all underpinned by a faith in free markets.

Twenty-first century capitalism has shifted in important ways that belie this earlier orientation. Key features of the contemporary era include the outsized role of intangibles in the global economy (e.g., intellectual property, services, financial instruments such as derivatives and securities), the rise of financialization, the quest for profits over economic growth, and the pursuit of competitiveness-not competition-in global markets. Twenty-first century capitalism has reduced advanced capitalist democracies' (like the US and the UK) capacity to offer robust and effective responses to

Susan K. Sell

susan.sell@anu.edu.au

1 School of Regulation and Global Governance, Australian National University, Acton, ACT, Australia
COVID-19. COVID-19 has exposed profound weaknesses in the structure of contemporary capitalism and offers an opportunity to re-think its role in shaping global health.

Going beyond the broad 'neoliberalism' label, John Braithwaite has described capitalism as 'variegated'; he identified two aspects that are particularly relevant to global health-'Wall Street' capitalism and 'monopoly capitalism' (Braithwaite 2019). Wall Street capitalism captures the globalization of finance and the increased economic and political power of the financial sector. Financial markets, motives, institutions and elites have come to dominate the global economy affecting everything from production, consumption, regulation and health (Epstein 2005). Monopoly capitalism, or 'intellectual monopoly capitalism' (Pagano 2014), captures intellectual property (e.g., patents, copyrights and trademarks) owners' preference to avoid competition. Ownership of intellectual property (IP) gives owners the right to exclude others from using the IP, reduce competitive supply and increase prices.

The quest to be competitive in global markets has led to economic concentration, oligopolies and a reduction in competition (Azmanova 2018). Economic power has shifted from the mainstays of the real economy (commodity producers and traders) to the controllers of global value chains (GVCs) who own intangibles such as intellectual property and financial instruments. According to Medeiros and 
Trebat,'the "core" business of every TNC (transnational corporation), irrespective of its particular branch, is to control and capitalize on these intangible assets' in order to maximize shareholder value and generate large rents (Medeiros and Trebat 2017: 407). Firms that are relatively immune to competitive pressure are 'less compelled to invest' in the real economy (Durand and Milberg 2018: 34). As Azmanova points out, 'competition-induced productivity ... does not condition growth on employment' and has resulted in socalled 'jobless growth' and 'jobless recovery' after economic crises (Azmanova 2012: 453). Economic globalization has reduced the power of labour and has accelerated an increase in 'labour flexibility' that translates into precarious employment. Post-the 2007-2008 global financial crisis, austerity programs, cuts in social spending and labour market transformation have had negative effects on health outcomes and health equity (De Vogli 2014).

Financialization has altered the behaviour of non-financial corporations. It prioritizes value extraction over value creation to maximize shareholder value. It sees innovation as a means to generate wealth, not to respond to people's health needs; it does not see health innovation as a way to facilitate the emergence and diffusion of higher-quality products at competitive cost (Mazzucato and Roy 2019). This has fundamentally reshaped the pharmaceutical industry from one characterized by multiple vertically-integrated firms, including everything from in-house $R \& D$ to clinical trials, to one that features far fewer firms that are horizontally integrated and expand largely through mergers and acquisitions (Gleadle et al. 2014; Busfield 2020). William Lazonick points out that in 2018 Merck and Pfizer grew large by acquiring blockbuster drugs developed by other companies, and then 'milking them for revenues over their remaining patent lives' (Lazonick 2018). Pharmaceutical executives' compensation is based on the price of company shares, so they have every incentive to boost it. They do this by buying back shares of their own stock on the open market, which became legal in 1982. For instance, in 2016 John C. Martin, CEO of Gilead Sciences earned \$98.4 million, of which $96 \%$ was stock-based pay (Tulum and Lazonick, 2018: 294-5). In just 3 years, 2017, 2018, and 2019 pharmaceutical firms spent $\$ 28.6$ billion on stock buybacks and just $\$ 10$ billion on R\&D (testimony of US House Representative Katie Porter, discussed in Wilkins 2020).

The strategic priority has changed from 'delivering value to customers (in the form of marketable products) to delivering value to creditors and shareholders' (Gleadle et al. 2014: 71). In the past firms would re-invest profits in their companies to develop new products and retain skilled personnel, but now most of the profits go to the creditors and institutional investors such as State Street and Black Rock that own majority shares (Busfield 2020). The three largest makers of N95 respirator masks, 3M, Honeywell and Kimberly-Clark, have also pursued this financialized approach and have tightly held the multiple patents on the masks (Lazonick and Hopkins 2020). Critical shortages of personal protective equipment such as N95 masks and ventilators have been partly due to the exclusive rights that IP confers. This has slowed down the production and distribution of this vital PPE. Ventilator production was hampered when larger firms acquired smaller innovative companies that were producing affordable ventilators in order to quash the potential competition and maintain the larger firms' higher prices (Kulish et al. 2020).

\section{Intellectual Monopoly Capitalism and Access to Medicines}

In the late 1970s and early 1980s, US-based IP owners lobbied for regulatory and legislative reform to expand IP protection. Pharmaceutical, software, publishing and entertainment producers argued that their industries provided America with competitive advantages in global markets. They sought the incorporation of IP into the trade regime to ensure that their IP would be remunerated in global markets and that trading partners would respect and enforce their 'rights'. By 1994 IP owners had succeed in globalizing their preferences through the Agreement on Trade-Related Intellectual Property Rights (TRIPs) in the World Trade Organization (Sell 2003). TRIPs is hard law; it is binding and enforceable. It mandates 20 years of patent protection for pharmaceutical products. Violations result in trade sanctions.

The institutionalization of intellectual property protection in the global trade regime cemented the shift from Reagan/ Thatcher neoliberalism to intellectual monopoly capitalism. When we talk about 'trade' these days, we are really discussing the role of intangibles such as IP and financial services. The main beneficiaries of contemporary trade agreements are those who control global value chains (GVCs), including international banks, Big Tech, Big Pharma, Big Food and Transnational Corporations. Lead firms in GVCs promote stricter IP requirements in trade agreements to 'contain the risk of IP appropriation resulting from the international fragmentation of production' (Durand and Milberg 2018: 21-22). Most of the post-TRIPs trade agreements in which IP-rich nations are involved feature IP provisions that extend well beyond the TRIPs obligations in the WTO. Today, 'profitability is a function of a firm's ability to extract monopoly rents from complex value chains using their control over IPRs' (Schwartz 2017: 197). For example, Apple extracts the lion's share of value from every iPad sold whereas the manufacturers in China receive only pennies on the dollar. 
Big Pharma routinely blocks pro-health initiatives aimed at promoting the use of TRIPs' flexibilities, such as compulsory licensing and parallel importation, that would make essential medicines affordable and accessible; these would threaten their profits and reduce shareholder value (Correa 2006). The profit imperative of financialized capitalism has meant that Big Pharma has invested far more in lifestyle diseases such as erectile dysfunction and baldness than in diseases of the Global South. As Feldman argues, 'our incentive structure is badly misaligned with societal goals' (Feldman 2018).

Patent protection increases prices and reduces access to medicines, diagnostics, vaccines, medical devices and PPE. Strategic behaviour aimed at blocking generic competition contributes to rising drug prices. Pharma firms routinely engage in 'evergreening' to extend patent protection terms. A firm may have a popular drug with an about-to-expire patent, and then offer a 'new' formulation-from a tablet to a gel cap—of the same drug and obtain another 20 years of protection. This strategic behaviour does not affect everyone equally. For example, during the HIV/AIDS pandemic of the late 1990s/early 2000s as deaths plummeted in affluent countries an estimated 12 million infected Africans were left to die, 'waiting for enough life-saving drugs to reach the continent' (Nkengasong et al. 2020: 198). India and South Africa have both asked the World Trade Organization to waive TRIPs provisions to allow them to engage in compulsory licensing and parallel importation of COVID-19 therapies (Reuters 2020). Their past experiences with HIV/AIDs and the swine and avian influenzas have bred understandable suspicion about the barriers to access that IP can create. As COVID-19 tests, therapies and vaccines are developed there is legitimate concern that intellectual property rights and reluctance to share related know-how may act as barriers to the rapid scale up for timely supply at affordable prices in all countries' (Tellez 2020).

The competitive scramble for COVID-19 vaccines is in full cry, with many affluent countries negotiating advance purchasing deals and raising concerns that the Global South will once again be 'left to die' (Torjesen 2020). The pandemic has exposed supply chain bottlenecks and overreliance on too-few suppliers that reduce the availability of needed inputs. Current collective efforts to develop COVID-19 vaccines, including the COVID-19 Vaccine Global Access (COVAX) initiative led by the World Health Organization (WHO), the Coalition for Epidemic Preparedness and Innovation (CEPI), and GAVI (the Vaccine Alliance) are promising and 167 countries have already signed up to it. The aim is to produce and distribute heavily subsidized vaccines to protect health care workers and vulnerable populations even in poor nations. However, questions about intellectual property protection remain and competition for vaccines is evident. The U.S. has made its own deals with several private firms; high-income countries have signed contracts with individual companies to buy vaccines, and the partnership between Oxford University and AstraZeneca raises questions about the non-profit versus for-profit future of vaccines in development (Nkengasong et al. 2020: 197; Garrison 2020).

Microsoft founder Bill Gates's generosity as a philanthropist has been remarkable, donating hundreds of millions of dollars to the Bill \& Melinda Gates Foundation to focus on health. However, the prominence of Bill Gates in the vaccine space also raises questions; he has been a major benefactor and ardent promoter of intellectual monopoly capitalism. The outsized role of global plutocrats such as Gates, whose personal wealth has increased by over $\$ 10$ billion during the pandemic, raises questions about governance for equity and the public good (McNamara and Newman 2020: 10; Schwab 2020). The Gates Foundation has invested over \$250 million in dozens of companies working on COVID-19 responses and stands to reap significant financial gains as a result. The financialization dynamic is evident in his $\$ 40$ million investment in CureVac, a German company. Just two days after CureVac's Initial Public Offering in August 2020, its stock value jumped $400 \%$, allowing investors to extract value (Schwab 2020). Given the Gates Foundation's outsized role in the pandemic response, its financial stakes should be accompanied by greater transparency and accountability. As a core beneficiary and supporter of both Wall Street and Monopoly capitalisms that have extravagantly enriched the few at the expense of the many, his role raises legitimate questions about the likelihood of further entrenching a badly skewed system during a global pandemic. Gates' preference for exclusive licenses for intellectual property does not bode well for widespread access over time. South Africa and India recognize this, as reflected in their request for TRIPs waivers in COVID-19 time.

\section{Inequality and Working Conditions}

The COVID-19 pandemic has revealed the lethal consequences of the sharp rise in economic inequality, the concentration of wealth in fewer and fewer hands and the increasing precarity of labour. For example, as COVID-19 slammed Manhattan, members of the top 1\% flocked to their beach retreats in the Hamptons to ride out the contagion (Sellinger 2020). Meanwhile, 'essential workers' at the bottom of the contemporary economic hierarchy had no options but to continue to show up for work and face exposure to the deadly virus. First responders, bus drivers, nursing home workers, janitors, postal workers, grocery stockers, agricultural workers, Wal-Mart employees, Amazon warehouse workers, delivery drivers, and meat packers-many earning minimum wage and most without employer-subsidized health insurance or other benefits-had to keep working. 
As Bertha Bradley, a food service worker in North Carolina stated, 'I don't get health benefits, I don't get sick time, I don't get paid vacations, I don't get a living wage' (Jaffe and Chen 2020: 126). Katie Pine and Kate Henne refer to them as 'new risk workers', many of whom are given mandates for minimizing risk but few resources to implement them (Pine and Henne 2020). For example, in the John H. Stroger Hospital in Chicago, nurses were being told to reuse N95 masks, 'sometimes up to forty-five days' (Jaffe and Chen 2020: 138). By contrast, knowledge workers could work from the safety of their own homes and reduce their risks of becoming infected.

COVID-19 has disproportionately attacked communities of colour, compounding economic inequality and systemic racism. It is clear that 'race matters for the way that markets have been built historically and function today' (McNamara and Newman 2020: 6). As Presidential candidate Joe Biden pointed out during the presidential debate in September 2020, 1 out of every one-thousand African Americans in the US has died from COVID-19. In Chicago about $70 \%$ of the COVID deaths were African Americans (Jaffe and Chen 2020: 140). The UN Secretary-General António Guterres pointed out that COVID-19 'is exposing fallacies and falsehoods everywhere ... the delusion that we live in a post-racist world, the myth that we are all in the same boat' (Guterres 2020). In September, Citigroup released a report that systemic racism, discrimination against African Americans, has cost the economy $\$ 16$ trillion (Akala 2020).

Many of the precariat are people of colour, recent immigrants and undocumented workers. By May 2020 slaughterhouses around the world became virus hot spots and exposed multiple layers of dysfunction. The meat processing industry is highly consolidated, dominated by global multinational corporations including Cargill, JBS, Smithfield and Tyson. Since the 1980s this industry has pursued the financialized model of consolidation and vertical integration, 'aimed at increasing profits through efficiency and low wages' (van der Zee et al. 2020). Many migrant workers in these plants live in communal housing; crowded working conditions, large plants and cramped housing, and lack of paid sick leave all exacerbate the spread of coronavirus in these environments. Indeed, Tyson was even offering workers $\$ 500$ bonuses to keep working in the midst of plant outbreaks (van der Zee et al. 2020). Workers are shouldering all of the risk as slaughterhouse companies get the rewards. Structures of the global economy, including financialization and monopoly capitalism have amplified the dangers of the pandemic and pushed people further 'into unequal groups that are not only divided by money but by matters of life and death' (McNamara and Newman 2020: 11; Sell and Williams 2019).

\section{Towards a More Compassionate Future?}

Viewed from a structural perspective, twenty-first century capitalism presents daunting challenges for imagining a more compassionate future. Globalization, economic interdependence, intertwined global supply chains, and concentrated economic and political power present a difficult web to reshape or even to untangle. Wall Street and Monopoly capitalisms powerfully shape the global political economy.

One may think of a spectrum of options from re-arranging the deck chairs on the Titanic to wholesale structural reform. Corporate social responsibility initiatives and philanthrocapitalism lie on the 'deck chair' end of the spectrum, regulatory reform lies in the middle, and a dramatic refashioning of capitalism to support global human and planetary health lies on the far end. The sheer scale and lethality of the COVID-19 pandemic, a virus that recognizes no class, nation, race or gender as immune, may provide us with an opportunity to rethink the system that has been laid bare in its face.

Wall Street capitalism has skewed the ratio of risk and reward with negative effects on innovation and distribution. Financialized capitalism excels at extracting value rather than creating it. This is clear in the pharmaceutical industry in which the focus on shareholder value has created warped incentives for executives to engage in stock buybacks to inflate stock prices and executive compensation. Value extracted in this way is typically not re-invested in the enterprise to retain skilled employees and innovate, but rather is used to pay out dividends and buy up small potential competitors or innovative firms. As Braithwaite suggests, the current system has increased 'political and economic power of banks and the rentier class (rentiers who live off income from investments in property or securities rather than from producing anything)' (Braithwaite 2019: 559). Huge tax cuts on capital gains, that Wall Street lobbyists have secured, have led to jobless recoveries and a severed link between productivity and job growth.

Meaningful regulatory reform of the banking sector and financial markets would include reforms to covert 'roaring banking' back into 'boring banking' (Epstein 2018). From the 1940s to the 1970s banks were boring in that they were restricted in the risks that they were permitted to take. Banking featured public missions to provide long term credit and housing finance, caps on interest rates and a moderate rate of return and stability in the sector (Epstein 2018). Creating a firewall between basic retail and investment banking, by reviving the Glass-Steagall Act of 1933, would prevent the contagion and collapse that spread from the shadow banking sector to the regulated banking sector in 1929 and in 2007-2008 (Fahri and Tirole 2020). Reducing the size of 'too-big-to-fail' banks and taxing financial transactions would also help curb the contemporary risky behaviour and 
damaging excesses in this sector. Returning to a model of economic growth rather than profit would include progressive taxation; 'in 1952 the highest income tax bracket in the United States was 92\% and the economy grew faster than ever' (Bregman 2020). Rescinding the US Securities and Exchange Commission's 1982 rule permitting stock buybacks would be a positive step to change incentives. Implementing curbs on capital flows and tax evasion would also serve to support policy space and additional resources to address public missions such as health care.

Robust antitrust or competition policy could boost IP reform to curb abuses of monopoly power across a range of sectors from Big Pharma, Big Food, and Big Tech among others. Beyond competition policy, a frank accounting of the value proposition of pharmaceutical products that is transparent about the percentages of public sector money behind the development of pharmaceutical products and medical devices would be a step in the right direction. As Mazzucato (2013), Mazzucato and Roy (2019), and Lazonick and Hopkins (2020) have all pointed out, most pharmaceutical innovation has been engineered by the 'entrepreneurial state' and funded by taxpayers. The public sector has taken the risks and the private sector is reaping nearly all of the rewards. This risk/reward ratio must be re-aligned to reflect the real value provided by public financing. Such transparency should serve to reduce the costs of essential medicines so that taxpayers do not end up paying twice for medicines. Alternative financing for drug development, such as prize funds, and the expansion of patent pools could be pursued. Intellectual property rights could be relaxed for public health needs, especially in a case such as COVID-19, as India and South Africa are requesting at the World Trade Organization. Relying on charity, and philanthro-capitalists whose fortunes and worldview reflect Wall Street and Monopoly capitalisms presents uncertain, unsustainable and even dangerous possibilities. Private interests and public interests are bound to clash to the detriment of the public at some juncture.

Addressing inequality and precarious labour has prompted calls for more structural reforms. The rhetoric of 'essential worker' offers an opportunity. Those designated as 'essential workers' during this pandemic are among the most poorly paid, most exposed to potentially fatal risks and lack access to basic health care and benefits, such as paid sick leave, that would help to protect themselves and others. Essential workers are those who take care of those who are most important and vulnerable, infants and children, elderly parents, the disabled and everyone else who needs stocked grocery shelves, home deliveries of food and medicine, education, and first responders. It is noteworthy that the Wall Street titans who retreated to the Hamptons during the Manhattan outbreak have not been designated as 'essential'.
This pandemic offers an opening to rethink what 'essential' really means and how essential work should be compensated. Living wages should be a basic human right. Albena Azmanova, a political theorist, calls for a 'more direct examination of capitalism' to identify 'points of fracture in today's capitalistic fabric' (Azmanova 2014: 357-8). She argues that those who seem to have conflicting grievances of ' 'labour-market insiders' who have good jobs but feel pressured to work harder and longer, and 'labour-market outsiders' (the unemployed and those in precarious employment) are mutually related via a political economy which increases and generalizes commodification pressures' (Azmanova 2014: 359). Thus, even the apparent 'winners' in the current system face increasing employment insecurity and these pressures indicate that 'something is wrong with our model of wellbeing' (Azmanova 2014: 359). The current system of competitive production of profit has produced 'systemic forms of injustice and domination such as the precariousness of livelihoods across the class divide' (Azmanova 2018: 8).

The neoliberal/libertarian mantra of individual responsibility and self-reliance has tattered social bonds and communal responsibility. It provides an excuse or rationale for the public sector to step back. Social safety has been removed as a legitimate public responsibility (Azmanova 2014: 361). And yet, as Bregman points out, 'humankind evolved to cooperate' and this insight can provide the basis for moving toward 'a government based on trust, a tax system rooted in solidarity, and the sustainable investments needed to secure our future' (Bregman 2020). Around the globe, governments have stepped up to provide temporary social protection in the pandemic at a massive scale. This has demonstrated that the public sector can mobilize vast resources in times of crisisthis time not to bail out banks that were too-big-to-fail, but to provide more social safety nets. The crisis has resuscitated serious conversations about a Universal Basic Income (UBI) to create conditions of economic certainty.

The rise of populism on the left and the right reflects a fear of freedom in a world that seems out of control. In the centre many are calling for reform to make capitalism more inclusive. But some call for a radical overhaul of the socio-economic system to develop a 'political economy of trust' to counter the 'systemic logic of domination at work in the contemporary modality of capitalism' (Azmanova 2014: 362). To begin to build such a system of trust, Azmanova advocates that those seeking to transform contemporary capitalism should challenge the rules that generate and sustain injustice rather than political actors (parties, states, foreigners etc.) (Azmanova 2018: 10).

This brief analysis of some of the structural aspects of contemporary capitalism(s) and the way they shape pandemic response highlights the importance of incorporating political economy into our discussions about public health. Understanding key features and pathologies of the current 
system can inspire constructive countermeasures to build resilience in the pandemic. For example, African experts from the African Center for Disease Control are mobilizing to deepen capacity to produce vaccines and manufacture PPE in the shadow of past negative experience with monopoly capitalism during the HIV/AIDS pandemic when so many were 'left to die' (Nkegasong et al. 2020). They have already developed testing capacity and have trained thousands of contact tracers. Robinson and Gilbert have called for the development of an 'economic bioethics' to illuminate 'how large structural changes-financialization, for example, or market consolidation ... increasingly structure both clinical decision-making and the decisions of individual scientists on the ground' (Robinson and Gilbert 2018). They call for bioethicists to engage with structural analysis to understand how macro-economic structures intersect with medical research and practice. This article seeks to contribute to promoting these types of connections by offering several illustrations of how twenty-first century capitalism intersects with COVID-19 and offering some glimpse into both the pathologies and opportunities for change going forward.

Funding This research was supported by the Australian Research Council grant DP180102426.

\section{References}

Akala, Adedayo. 2020. Cost of Racism: U.S. Economy lost \$16 trillion because of discrimination bank says, NPR, 23 September. https://www.npr.org/sections/live-updates-protests-for-racial-justi ce/2020/09/23/916022472/cost-of-racism-u-s-economy-lost16-trillion-because-of-discrimination-bank-says

Azmanova, Albena. 2018. The Populist Catharsis: On the revival of the political. Philosophy and Social Criticism 44 (4): 399-411. https ://doi.org/10.1177/0191453718760091.

Azmanova, Albena. 2014. Crisis? Capitalism is Doing Very Well. How is Critical Theory? Constellations 21 (3): 351-365. https://doi. org/10.1111/1467-8675.12101.

Azmanova, Albena. 2012. Social Justice and Varieties of Capitalism: An immanent critique. New Political Economy 17 (4): 445-463. https://doi.org/10.1080/13563467.2011.606902.

Braithwaite, John. 2019. Tempered Power, Variegated Capitalism, Law and Society. Buffalo Law Review 67 (3): 527-594.

Bregman, Rutger. 2020. The Neoliberal Era is Ending. What comes next?, The Correspondent, 14 May. https://thecorresponden t.com/466/the-neoliberal-era-is-ending-what-comes-next/61655 148676-a00ee 89 a

Busfield, Joan. 2020. Documenting the Financialisation of the Pharmaceutical Industry. Social Science and Medicine 258 (113096): 1-8. https://doi.org/10.1016/j.socscimed.2020.113096.

Correa, Carlos. 2006. Implications of Bilateral Free Trade Agreements on Access to Medicines. Bulletin of the World Health Organization 84 (5): 399-404.

De Medeiros, Carlos Aguiar., and Nicholas Trebat. 2017. Inequality and Income Distribution in Global Value Chains. Journal of Economic Issues. 51 (2): 401-408.
De Vogli, Roberto. 2014. The Financial Crisis, Health and Health Inequities in Europe: The Need for Regulations, Redistribution and Social Protection, International Journal for Equity in Health, July, 13(58). https://doi.org/10.1186/s12939-014-0058-6

Durand, Cédric and William Milberg. 2018. Intellectual Monopoly in Global Value Chains, Working Paper 07/2018. Department of Economics. The New School for Social Research. https://hal. archives-ouvertes.fr/hal-01850438/document

Epstein, Gerald. 2018. On the Social Efficiency of Finance. Development and Change 49 (2): 330-352.

Epstein, Gerald A. 2005. Introduction. In Financialization and the World Economy, ed. Gerald A. Epstein, 3-16. Cheltenham: Edward Elgar.

Gleadle, Pauline, Stuart Parris, Alan Shipman, and Roberto Simonetti. 2014. Restructuring and Innovation in Pharmaceuticals and Biotechs: The Impact of Financialisation. Critical Perspectives on Accounting 25 (1): 67-77. https://doi.org/10.1016/j. cpa.2012.10.0003.

Fahri, Emmanuel and Jean Tirole. 2020. Shadow Banking and the Four Pillars of Traditional Financial Intermediation, NBER Working Paper, No. 23930. https://doi.org/10.3386/w23930. https://www.nber.org/papers/w23930

Feldman, Robin. 2018. May Your Drug Price Be Evergreen. Oxford Journal of Law and the Biosciences 5 (3): 590-647.

Garrison, Christopher. 2020. How the 'Oxford' Covid-19 Vaccine became the 'AstraZeneca' Covid-19 Vaccine, Medicines Law \& Policy. https://medicineslawandpolicy.org/2020/10/howthe-oxford-covid-19-vaccine-became-the-astrazeneca-covid -19-vaccine/

Guterres, António. 2020. Tackling the Inequality Pandemic: A new social contract for a new era. The Nelson Mandela Lecture, 18 July. https://www.un.org/en/coronavirus/tackling-inequality-newsocial-contract-new-era

Jaffe, Sarah, and Michella Chen. 2020. Work in the time of Coronavirus: Belabored stories. Dissent 67 (1(Summer)): 125-148.

Kulish, Nicholas, Sarah Kliff, and Jessica Silver-Greenberg. 2020. The U.S. Tried to Build a New Fleet of Ventilators. The Mission Failed. The New York Times, 29 March. https://www.nytim es.com/2020/03/29/business/coronavirus-us-ventilator-shortage. html

Lazonick, William. 2018. The Curse of Stock Buybacks, The American Prospect (June 25).

Lazonick, William and Matt Hopkins. 2020. How "Maximizing Shareholder Value" Minimized the Strategic National Stockpile: The \$5.3 Trillion Question for Pandemic Preparedness Raised by the Ventilator Fiasco, July. https://www.ineteconomics.org/research/ research-papers/how-maximizing-shareholder-value-minimizedthe-strategic-national-stockpile-the-5-3-trillion-question-forpandemic-preparedness-raised-by-the-ventilator-fiasco

Mazzucato, Mariana. 2013. The Entrepreneurial State. London: Anthem Press.

Mazzucato, Mariana, and Victor Roy. 2019. Rethinking Value in Health Innovation: From Mystifications Towards Prescriptions. Journal of Economic Policy Reform 22 (2): 101-119. https://doi. org/10.1080/17487870.2018.1509712.

McNamara, Kathleen, and Abraham L. Newman. 2020. The Big Reveal: COVID-19 and Globalization's Great Transformations. International Organization 74 (Supplement 2020): 1-19. https:// doi.org/10.1017/S0020818320000387.

Nkengasong, John N., Nicaise Ndembi, Akhona Tshangela, and Tajudeen Raji. 2020. COVID-19 Vaccines: How to ensure Africa access. Nature 586: 197-199.

Pagano, Ugo. 2014. The Crisis of Intellectual Monopoly Capitalism. Cambridge Journal of Economics 38: 1409-1431.

Pine, Kathleen H., and Kathryn Henne. 2020. Navigation practices in times of extended crisis: Preliminary findings from a comparative 
study. 15 September. Presentation at School of Regulation and Global Governance, Australian National University.

Reuters. 2020. India and South Africa ask WTO to Waive Rules to aid COVID-19 Drug Production, 4 October. https://timesofindia.india times.com/india/india-and-south-africa-ask-wto-to-waive-rules -to-aid-covid-19-drug-production/articleshow/78476730.cms

Robinson, Mark Dennis and Joseph M. Gilbert. 2018. 'Designing an Economic Bioethics', https://blog.petrieflom.law.harva rd.edu/2018/10/10/designing-an-economic-bioethics/

Schwab, Tim. 2020. While the Poor Get Sick, Bill Gates Just Gets Richer, The Nation, 5 October. https://www.thenation.com/artic le/economy/bill-gates-investments-covid/

Schwartz, Herman Mark. 2017. Club Goods, intellectual property rights and profitability in the information economy. Business and Politics 19 (2): 191-214.

Sell, Susan K. 2003. Private Power, Public Law: The Globalization of Intellectual Property Rights. Cambridge, UK: Cambridge University Press.

Sell, Susan K., and Owain D. Williams. 2019. Health Under Capitalism: A global political economy of structural pathogenesis. Review of International Political Economy 27 (1): 1-25. https:// doi.org/10.1080/09692290.2019.1659842.

Sellinger, Hannah. 2020. In the Hamptons, Coronavirus Heightens Tensions, Curbed, 8 April, https://archive.curbed.com/2020/4/8/21213 468/coronavirus-hamptons-vacation-homes-neighbors-covid-19

Tellez, Viviana Munoz. 2020. Action at the WTO is needed to accelerate research, development, manufacturing and supply of medical products to combat Covid-19: Proposal from India and South Africa, South Centre SOUTHNEWS, 5 October, No. 341

Torjesen, Ingrid. 2020. Covid-19: Pre-purchasing vaccine-Sensible or selfish?, BMJ, 14 August. https://www.bmj.com/content/bmj/370/ bmj.m3226.full.pdf

Tulum, Öner., and William Lazonick. 2018. Financialized Corporations in a National Innovation System: The U.S. Pharmaceutical Industry. International Journal of Political Economy 47 (3-4): 281-316.

Van der Zee, Bibi, Tom Levitt, and Ella McSweeney. 2020. 'Chaotic and crazy': Meat plants around the world struggle with virus outbreaks, The Guardian, 11 May. https://www.theguardian.com/ environment/2020/may/11/chaotic-and-crazy-meat-plants-aroun d-the-world-struggle-with-virus-outbreaks

Wilkins, Brett. 2020. Katie Porter Eviscerates Big Pharma CEO over 'exorbitant' drug prices, Salon. 4 October. https://www.salon .com/2020/10/04/katie-porter-eviscerate-big-pharma-ceo-overexorbitant-drug-prices_partner/

Publisher's Note Springer Nature remains neutral with regard to jurisdictional claims in published maps and institutional affiliations. 